\title{
PENGARUH PENGGUNAAN PEREKAT SAGU DAN TAPIOKA TERHADAP KARAKTERISTIK BRIKET DARI BIOMASSA LIMBAH PENYULINGAN MINYAK KAYU PUTIH DI MALUKU
}

\section{THE EFFECT OF SAGO AND TAPIOCA USED AGAINST BRIQUETTE CHARACTERISTICS FROM BIOMASS WASTE OF REFINING CAJUPUT OILS IN MALUKU}

\author{
Husein Smith dan Syarifuddin Idrus \\ Baristand Industri Ambon, Jl. Kebun Cengkeh Batu Merah Ambon \\ E-mail : husein.smtih@yahoo.com
}

Received : 13/12/2017; revised : 28/12/2017; accepted : 28/12/2017

Published online : 29/12/2017

\begin{abstract}
ABSTRAK
Biomassa adalah materi biologis yang dapat digunakan sebagai sumber bahan bakar, baik secara langsung maupun melalui proses yang dikenal sebagai konversi biomassa. Biomassa di Maluku yang dapat dikonversi menjadi sumber energi panas alternatif salah satunya limbah daun penyulingan minyak kayu putih. Biomassa ini diharapkan dapat untuk mengatasi kebutuhan bahan bakar dipedesaan. Penelitian ini dilakukan untuk mengetahui kondisi optimum perlakuan yang diujicobakan dan karakteristik biobriket dari limbah penyulingan minyak kayu putih yang dibuat dengan perekat sagu dan tapioka. Desain experimen yang digunakan pada penelitian ini yaitu completelly randomized design dengan perlakuan persentase penggunaan perekat tapioka dan sagu masing-masing $80-130 \%$ terhadap serbuk limbah penyulingan minyak kayu putih. Hasil penelitian menunjukkan bahwa perlakuan jumlah perekat sagu dan tapioka berpengaruh sangat signifikan terhadap kadar air, kadar abu, kerapatan dan zat yang hilang pada pemanasan $950{ }^{\circ} \mathrm{C}$. Hubungan antara penggunaan jumlah perekat sagu maupun tapioka pada pembuatan biobriket dengan berbagai variabel respon tersebut mengikuti pola linier dengan trend garis yang berbeda antar setiap variabel. Penggunaan perekat tapioka $130 \%$ terhadap serbuk limbah penyulingan minyak kayu putih menghasilkan briket dengan kerapatan dan zat yang hilang pada pemanasan $950{ }^{\circ} \mathrm{C}$ tertinggi sedangkan kadar air dan kadar abu terendah masing-masing $0,52 \mathrm{~g} / \mathrm{cm}^{3}, 8,95 \%$, $5,88 \%$ dan 6,82 \%. Rata-rata nilai kalor limbah penyulingan minyak kayu putih 4567,19 kal/g. Briket yang diperoleh memiliki nilai kadar air, zat yang hilang dan nilai kalor memenuhi standar karakteristik briket untuk rumah tangga.
\end{abstract}

Kata kunci : Biobriket, limbah penyulingan minyak kayu putih, perekat sagu, tapioka

\begin{abstract}
Biomass is biological material that can be used as source of fuel, either directly or through process known as biomass conversion. The biomass potential in the Molluca can be converted into thermal energy source is an alternative waste leaves distillation eucalyptus oil. This biomass is expected to overcome the needs of fuel in the countryside. This research was conducted to determine the optimum condition and biobriket characteristic of the waste of eucalyptus leaves using sago and tapioca adhesive. Design experiment used in this study is a randomized design with completely treatment the percentage of adhesive tapioca and sago respectively $80-130$ $\%$ of the waste powder eucalyptus oil refinery. Results showed that the amount of adhesive sago and tapioca very significant influence on moisture, ash, density and substance lost on heating $950{ }^{\circ} \mathrm{C}$. The relationship between the uses of sago or tapioca adhesive starch in the manufacture of various biobriket with the response variable follow a linear pattern with a trend line that is different between each variable. Use adhesive tapioca powder $130 \%$ of waste distillation of eucalyptus oil to produce briquettes with density and nutrient loss at heating $950^{\circ} \mathrm{C}$, while the highest rate of water and ash content lower respectively $0,52 \mathrm{~g} / \mathrm{cm}^{3}, 8.95 \%, 5.88 \%$ and $6.82 \%$. The average calorific value of the waste oil destillation eucalyptus $4567.19 \mathrm{cal} / \mathrm{g}$. The briquette was satisfying the standard characteristics of briquettes for home industry.
\end{abstract}

Key words : Biobriket, waste distillation of eucalyptus oil, sago adhesive, tapioca

\section{PENDAHULUAN}

Energi merupakan permasalahan utama dunia saat ini. Tiap tahun kebutuhan akan energi semakin meningkat seiring dengan meningkatnya aktivitas manusia yang menggunakan bahan bakar terutama bahan bakar minyak yang diperoleh dari fosil 
tumbuhan maupun hewan. Ketersediaan bahan bakar fosil yang semakin langka berakibat pada kenaikan harga BBM, oleh karena itu diperlukan suatu alternatif untuk mengurangi penggunaan bahan bakar minyak. Salah satu alternatif tersebut yaitu dengan penggunaan energi biomassa. Energi biomassa merupakan sumber energi yang berasal dari sumber daya alam yang dapat diperbaharui sehingga berpeluang untuk dimanfaatkan sebagai bahan bakar alternatif.

Di Indonesia kebutuhan dan konsumsi energi terfokus pada penggunaan bahan bakar minyak yang cadangannya makin menipis sedangkan pada sisi lain terdapat energi biomassa yang jumlah cukup melimpah namun penggunaannya belum optimal.

Penyediaan energi biomassa dalam konstelasi pembangunan nasional sangat penting meskipun kontribusinya terhadap total konsumsi energi nasional sangat kecil. Energi biomassa, khususnya kayu bakar, masih merupakan sumber energi dominan bagi masyarakat pedesaan yang pada umumnya berpenghasilan rendah. Diperkirakan 50\% penduduk Indonesia menggunakan kayu bakar sebagai sumber energi dengan tingkat konsumsi 1,2 $\mathrm{m}^{3}$ /orang/tahun (Tampubolon 2008).

Penggunaan energi terbarukan (renewable energy) dalam konteks diversifikasi energi sangat strategis karena sejalan dengan pembangunan berkelanjutan (sustainable development) dan ramah lingkungan (emisi gas rumah kaca relatif rendah). Hal ini diatur dalam Peraturan Presiden No.5/2006 tentang kebijakan Energi Nasional. Selain Peraturan Presiden tersebut ada beberapa kebijakan dan peraturan yang terkait dengan energi biomassa serta sektor kehutanan diantaranya Blueprint Pengelolaan Energi Nasional 2005 - 2025, sebagai dasar penyusunan pola pengembangan dan pemanfaatan masing-masing energi nasional.

Kebijakan pengembangan energi biomassa ini untuk meningkatkan kapasitas masyarakat menengah ke bawah dan UMKM sekitar hutan dalam pengolahan dan pemanfaatan biomassa secara efisien sebagai sumber energi untuk mengurangi beban pemerintah dalam pemenuhan BBM (Tim Pengembangan Biomassa Departemen Kehutanan 2007).

Salah satu kendala utama yang dihadapi untuk mendorong perkembangan industri kecil di Maluku, terutama daerah marginal di pedesaan yaitu ketersediaan energi. Pada umumnya, penyediaan energi untuk menopang kehidupan masyarakat di daerah berkondisi marginal sangat bergantung pada BBM dan kayu bakar.
Kondisi perekonomian masyarakat desa di Maluku masih rendah, hal ini dapat dilihat dari persentase jumlah Penduduk desa miskin di Maluku sebesar 26,7\% (BPS 2015) mengakibatkan permasalahan muncul setiap kali terjadi kenaikan harga minyak tanah. Bahan bakar minyak tanah dengan fokus pemanfaatan untuk keperluan memasak kerapkali menjadi isu permasalahan dan perbincangan karena pengaruhnya terhadap kesejahteraan masyarakat setempat sangat signifikan. Akibat lain yang dapat terjadi yaitu peningkatan konsumsi kayu bakar yang mengancam kelestarian lingkungan. Bahan bakar kayu yang perolehannya semakin sulit apalagi dengan gencarnya isu global tentang pelestarian lingkungan hidup, maka perlu ada solusi bahan bakar alternatif. Salah satu solusinya dengan memanfaatkan biomassa dari limbah penyulingan minyak kayu putih.

Limbah penyulingan minyak kayu putih di Maluku dapat diperoleh dari industri kecil penyulingan yang ada di pedesaan yang selama ini limbah tersebut belum dimanfaatkan, dibuang disekitar areal penyulingan dalam jumlah banyak sampai membusuk, sehingga bisa digunakan sebagai energi alternatif pengganti kayu bakar. Hal ini ditunjang oleh potensi hutan kayu putih di Maluku yang tersebar di beberapa Kabupaten, yaitu Kabupaten Buru 120.000. ha, Kabupaten Seram Bagian Barat 50.000 ha. Kabupaten Maluku Tenggara Barat 20.000 ha dan Kabupaten Maluku Tengah 60.000 ha (BPS 2014). Pemanfaatan biomassa dari limbah penyulingan minyak kayu putih tersebut sebagai sumber energi panas dapat diolah menjadi bahan bakar padat dalam bentuk briket yang merupakan salah satu alternatif pemanfaatan limbah pada industri kecil penyulingan minyak kayu putih di Maluku.

Biobriket merupakan bahan bakar berwujud padat yang berasal dari sisa-sisa bahan organik yang telah mengalami proses pemampatan dengan daya tekan tertentu (Hambali et al 2008). Pembriketan pada dasarnya densifikasi atau pemampatan bahan baku yang bertujuan untuk memperbaiki sifat fisik suatu bahan sehingga memudahkan penanganannya ( Abdullah 2002). Penelitian Zhang dan Guo (2014), menyatakan bahwa ukuran partikel merupakan faktor paling utama yang mempengaruhi sifat fisis briket, diikuti kandungan air dan suhu. Briket bermutu adalah briket yang mempunyai ukuran partikel kecil, kandungan air rendah dan memiliki nilai kalor tinggi. Penelitian ini sejalan dengan Saptoadi dkk (2009), tentang dimensi dan ukuran partikel pada biobriket, menunjukkan bahwa dimensi briket harus 
sekecil mungkin, tetapi partikel penyusun briket harus yang paling kasar.

Proses pembuatan briket arang memerlukan perekatan yang bertujuan untuk mengikat partikel-partikel arang sehingga menjadi kompak. Bahan perekat yang baik digunakan untuk pembuatan briket arang meliputi pati, dekstrin dan tepung tapioka, karena menghasilkan briket arang yang tidak berasap pada saat pembakaran dan tahan lama (Permatasari dan Utami 2015). Perekat yang sering digunakan pada pembuatan briket antara lain kanji, sagu, tanah liat, semen, natrium silikat dan tetes tebu. Beberapa penelitian sebelumnya yang dilakukan oleh Sutiyono (2002) membandingkan antara perekat kanji dengan perekat tetes tebu dan dihasilkan briket yang optimum yaitu briket yang menggunakan bahan perekat kanji karena memiliki kuat tekan dan nilai kalor yang lebih tinggi. Penelitian lain dilakukan oleh Lestari et al (2010) yang membandingkan antara perekat sagu dan perekat kanji. Dari hasil penelitian tersebut juga dihasilkan perekat yang lebih baik yaitu perekat kanji karena memiliki kandungan air dan abu yang rendah dan karbon yang lebih tinggi dibandingkan dengan perekat sagu.

Penelitian tentang briket dari biomassa senbagai bahan bakar alternatif untuk mengurangi krisis energi juga dilakukan Gomez et al (2014), dengan cara membangun Digital Elevation Model yang terbuat dari batang jagung dicampur serbuk kayu gergaji, sekam padi, tunas tanaman rambat, dan jerami. Penelitian lain tentang biomassa juga dilakukan oleh Longjian et al (2009) yang menunjukkan bahwa sumber daya limbah pertanian yang melimpah dapat digunakan sebagai bahan baku yang ekonomis dan berkelanjutan untuk pnengembangan bahan bakar padat di Cina. Adapun hasil penelitian Jianfeng et al (2010) menunjukkan bahwa di antara berbagai teknologi konversi, pembakaran merupakan cara yang paling umum dan dikembangkan untuk mengkonversi bahan bakar biomassa menjadi energi.

Penelitian yang dilakukan Stolarski et al (2013), menunjukkan bahwa nilai kalor tertinggi diperoleh pada briket dari serbuk gergaji. Briket serbuk gergaji pengaruhnya $0,40 \%$ terhadap kandungan abu. Sedangkan hasil penelitian energi alternatif biomassa yang dilakukan Simone et al (2014), dengan cara mendidihkan air, rata-rata efisiensi termalnya $18 \%$, selanjutnya untuk memasak membutuhkan 4,2 MJ per kg makanan yang dimasak. Penelitian Simone et al (2014) ini difokuskan untuk membantu akses energi di tingkat rumah tangga yang berpenghasilan rendah, dengan memanfaatkan limbah pertanian sebagai bahan bakar.

Pembuatan biobriket dapat memberikan keuntungan antara lain kerapatannya meningkat, bentuknya rapi dan ukuran seragam sehingga memudahkan untuk dibawa dan digunakan sebagai bahan bakar rumah tangga dan industri kecil. Manfaat biobriket menurut Kong (2010) sangat mudah untuk distribusi ke daerah pengguna, mudah disimpan, dengan harga yang murah, dapat membantu rumah tangga sederhana memperoleh bahan bakar untuk keperluan memasak, dapat dimanfaatkan juga untuk proses produksi UKM dan bisa menggantikan kebutuhan batu bara. Dari uraian tersebut menunjukkan bahwa biobriket merupakan salah satu solusi energi alternetif, untuk itu dilakukan penelitian dengan tujuan memanfaatkan biomassa limbah penyulingan minyak kayu putih di Maluku sebagai bahan bakar

\section{METODE PENELITIAN}

\section{Pelaksanaan Penelitian}

Limbah penyulingan daun kayu putih (Melaleuca leucadendron) yang digunakan untuk pembuatan biobriket diperoleh dari indutri kecil penyulingan minyak kayu putih di Pulau Buru Provinsi Maluku. Sebelum dilakukan pembriketan, biomassa dari limbah tersebut dijemur sampai kering udara kemudian dibuat serbuk dengan cara digiling menggunakan mesin penggiling. Serbuk limbah daun kayu putih tersebut di campur dengan perekat organik sagu dan tapioka konsentrasi 15\% hingga terbentuk adonan homogen kemudian dicetak. Hasil cetakan biobriket diangin-anginkan selanjutnya dikeringkan dalam oven dengan suhu $65^{\circ} \mathrm{C}$ selama 24 jam dan dikondisikan selama 2 hari pada suhu kamar kemudian dilakukan pengamatan terhadap peubah respon. Peralatan penelitian terdiri dari oven, neraca, tanur, kaliper, cetakan briket dan seperangkat alat laboratorium.

\section{Analisis Data}

Penelitian ini menggunakan factorial experiments dalam completely randomize design dengan perlakuan persentase perekat organik terhadap limbah penyulingan daun kayu putih (A); $80 \%\left(a_{1}\right)$, $90 \%\left(a_{2}\right), 100 \%\left(a_{3}\right), 110 \%\left(a_{4}\right), 120 \%$ $\left(a_{5}\right), 130 \%\left(a_{6}\right)$ dan jenis perekat organik (B); perekat sagu $\left(b_{1}\right)$, perekat tapioka $\left(b_{2}\right)$. Model linier aditif dari rancangan penelitian ini adalah $Y_{i j k}=\mu+\alpha_{i}+\beta_{j}+\alpha \beta_{(i j)}+\varepsilon_{i j k}$. Dimana $Y_{i j k}$ adalah nilai pengamatan faktor A taraf $k e-i$, faktor $B$ taraf $k e-j$ dan 
ulangan ke-k $\left(\mu, \alpha_{i}, \beta_{j}\right) \quad$ merupakan komponen aditif dari rataan, pengaruh utama faktor A dan faktor B. $\alpha \beta_{(i j)}$ merupakan komponen interaksi dari faktor A dan faktor $\mathrm{B}$, sedangkan $\varepsilon_{i j k}$ adalah pengaruh acak (Anshori dan Sumertajaya 2000).

Untuk mengetahui pengaruh perlakuan faktor tunggal dan interaksinya terhadap peubah respon biobriket, maka perlu dikonstruksikan hipotesis sebelum dilakukan pengujian hipotesis tersebut, Dalam penelitian kuantitatif, hipotesis merupakan elemen penting sebagai peranti kerja peneliti yang perlu di uji atau dibuktikan secara empiris. Konstruksi hipotesis statistik pada penelitian ini sebagai berikut:

$H_{0}: \alpha_{i}=0$; faktor A tidak mempengaruhi peubah respon biobriket.

$H_{1}: \alpha_{i} \neq 0 ;$ minimal ada satu taraf faktor A mempengaruhi peubah respon.

$H_{0}: \beta_{j}=0$; faktor $B$ tidak berpengaruh terhadap peubah respon biobriket

$H_{0}: \beta_{j} \neq 0$; minimal ada satu taraf faktor $B$ mempengaruhi peubah respon

$H_{0}: \alpha \beta_{(i j)}=$; interaksi perlakuan tidak berpengaruh pada peubah respon

$H_{1}: \alpha \beta_{(i j)}=$; minimal ada satu interaksi perlakuan berpengaruh pada peubah respon

\section{HASIL DAN PEMBAHASAN}

Hasil penelitian pembuatan biobriket dari limbah biomassa penyulingan daun kayu putih dengan berbagai perlakuan persentase perekat organik terhadap berat limbah penyulingan minyak kayu putih diperlihatkan pada Tabel 1

Tabel 1. Rekapitulasi Rataan Peubah Respon Biobriket Pada Berbagai Perlakuan.

\begin{tabular}{|c|c|c|c|c|c|c|c|c|c|c|c|c|}
\hline \multirow{2}{*}{$\begin{array}{l}\text { Peubah } \\
\text { respon }\end{array}$} & \multicolumn{12}{|c|}{ Penggunaan perekat organik } \\
\hline & $a_{1} b_{1}$ & $a_{2} b_{1}$ & $a_{3} b_{1}$ & $a_{4} b_{1}$ & $a_{5} b_{1}$ & $a_{6} b_{1}$ & $a_{1} b_{2}$ & $a_{2} b_{2}$ & $a_{3} b_{2}$ & $a_{4} b_{2}$ & $a_{5} b_{2}$ & $a_{6} b_{2}$ \\
\hline $\begin{array}{l}\text { Kadar alr } \\
(\%)\end{array}$ & 89 & 12,39 & 12,15 & 11,16 & 9,56 & 6,03 & 12,12 & 11,82 & 11,50 & 11,02 & 10,45 & 5,88 \\
\hline $\begin{array}{l}\text { Kadar ab } \\
(\%)\end{array}$ & 6,29 & 6,69 & 94 & 7,80 & 8,17 & 56 & 20 & 5,65 & 6,18 & 6,60 & ,74 & 6,82 \\
\hline $\begin{array}{l}\text { Density } \\
\left(\mathrm{g} / \mathrm{cm}^{3}\right)\end{array}$ & 0,368 & 0,420 & 0,453 & 0,485 & 0,528 & 0,575 & 0,350 & 0,383 & 0,398 & 0,430 & 0,485 & 0,520 \\
\hline $\begin{array}{l}\text { Zat yang } \\
\text { hilang (\%) }\end{array}$ & 5,06 & 5,60 & 6,05 & 6,40 & 7,91 & 10,44 & 4,27 & 5,30 & 5,38 & 5,82 & 7,17 & 8,95 \\
\hline
\end{tabular}

\section{Kadar Air}

Penentuan kadar air dilakukan untuk mengetahui sifat higroskopis biobriket. Kadar air sangat mempengaruhi kualitas briket arang yang dihasilkan. Semakin rendah kadar air maka nilai kalor dan daya pembakaran akan semakin tinggi dan sebaliknya semakin tinggi kadar air maka nilai kalor dan daya pembakaran akan semakin rendah. Kadar air briket juga dapat menentukan sifat higroskopis dari briket tersebut. Briket yang memiliki kadar air tinggi akan sulit dinyalakan, mudah rapuh dan ditumbuhi jamur (Maryono dkk 2013).

Pada Tabel 1. terlihat bahwa kadar air biobriket yang dibuat dari limbah penyulingan minyak kayu putih pada berbagai perlakuan berkisar 5,88\% - 12,89\%, kadar air tertinggi terdapat pada biobriket yang dibuat menggunakan perekat sagu $80 \%$ terhadap berat limbah penyulingan minyak kayu putih sedangkan terendah terdapat pada biobriket yang dibuat menggunakan perekat tapioka dengan jumlah $130 \%$. Makin tinggi penggunaan jumlah perekat sagu dan tapioka pada pembuatan biobriket, cenderung mengakibatkan terjadi penurunan kadar air biobriket. Sedangkan penggunaan perekat sagu, rata-rata kadar air biobriket yang dihasilkan lebih tinggi $0,24 \%$ bila dibandingkan penggunaan perekat tapioka.

Hasil analisa varians menunjukkan bahwa ada pengaruh yang sangat signifikan dari perlakuan penggunaan jumlah perekat terhadap kadar air biobriket sedangkan jenis perekat dan interaksi keduanya masing-masing menunjukkan pengaruh signifikan dan sangat signifikan terhadap kadar air (Tabel 1). Dari hasil analisis ini terbukti secara empiris bahwa hipotesis $H_{0}$ dalam penelitian ini diterima pada tingkat 
kepercayaan 99\% untuk penggunaan jumlah perekat dan interaksinya sedangkan untuk penggunaan jenis perekat hipotesisnya diterima pada.tingkat kepercayaan 95\%.

Makin tinggi jumlah perekat yang digunakan pada pembuatan biobriket, makin kecil kadar air dari biobriket tersebut. Hal ini disebabkan karena pada penggunaan jumlah perekat yang tinggi, lebih banyak partikel-partikel limbah penyulingan daun kayu putih yang membentuk biobriket dibungkus atau dikelilingi oleh perekat, sehingga absorbsi uap air oleh partikel limbah daun kayu putih dari lingkungannya lebih rendah. Keadaan ini berlaku sebaliknya terhadap biobriket yang dibuat dengan jumlah perekat yang lebih kecil.

Kemampuan briket untuk mengabsorbsi atau melepaskan air tergantung pada suhu dan kelembaban udara sekitarnya, akibatnya kandungan air briket berubah-ubah sesuai keadaan udara sekitarnya. Perubahan kadar air pada briket akibat dari kelembaban nisbi dan suhu udara yang merupaka fungsi waktu, artinya mulanya briket akan menyesuaikan diri kemudian semakin lambat mendekati kadar air seimbang. Purwanto (2015) melaporkan bahwa kadar air biobriket tempurung sawit dipengaruhi sangat nyata oleh ukuran partikel serbuk dan tekanan kempa sedangkan interaksinya berpengaruh nyata, makin besar ukuran mesh dan tekanan kempa kadar air cenderung menurun.

Dari uji Tukey menunjukkan bahwa ada perbedaan yang sangat nyata antar interaksi perlakuan terhadap kadar air biobriket, namun tidak semua interaksi perlakuan berbeda nyata sedangkan hasil uji beda terhadap jenis perekat yang digunakan menunjukkan bahwa terdapat perbedaan yang sangat nyata terhadap kadar air biobriket. Kadar air selain dipengaruhi oleh kelembaban dan suhu udara, erat kaitannya juga dengan sifat fisik biobriket terutama kerapatan. Menurut Bahri (2008), semakin tinggi kerapatan maka rongga-rongga antar partikel biobriket akan semakin rapat karena ikatan partikel sehingga celah atau ruang kosong terisi uap air semakin kecil. Pada umumnya kadar air yang tinggi akan menurunkan nilai kalor dan laju pembakaran karena panas digunakan terlebih dahulu untuk menguapkan air yang terdapat di dalam briket. Penelitian yang dilakukan Putro et al (2013), tentang kadar air briket menunjukkan bahwa persen kontribusi yang diberikan oleh tekanan, waktu penahanan, komposisi limbah, perekat dan suhu pengeringan masing-masing sebesar 6,97; 43,19; 18,76; 10,65 dan 19,37\%. Penelitian sebelumnya yang dilakukan Putro et al (2013) tentang kadar air biobriket menunjukkan bahwa komposisi terbaik yang dapat meminimalkan kadar air biobriket dengan perbandingan limbah jarak pagar $60 \mathrm{~g}$, komposisi arang sekam $40 \mathrm{~g}$, komposisi serbuk gergaji $20 \mathrm{~g}$, perekat tetes tebu dan suhu pengeringan $105^{\circ} \mathrm{C}$.

Hasil penelitian menunjukkan juga bahwa briket yang dibuat menggunakan perekat tapioka kadar airnya lebih rendah 0,24\% dibandingkan briket yang dibuat dengan perekat sagu. Hasil uji Tukey terhadap kedua jenis perekat tersebut menunujukkan ada perbedaan yang sangat signifikan terhadap kadar air briket yang dihasilkan. Sejalan dengan hasil penelitian Zulfian et al (2015), yang menyatakan bahwa faktor perekat juga berperan penting dalam peningkatan kadar air biopelet. Penggunaan perekat tepung sagu cenderung menghasilkan kadar air lebih tinggi daripada perekat tapioka. Hal ini dapat disebabkan kandungan air bawaan dari kedua jenis perekat, dimana tepung sagu memiliki kadar air lebih tinggi dibandingkan kandungan kadar air tepung tapioka (Lestari et al 2010).

Selain kadar air bawaan yang terdapat pada perekat sagu dan tapioka yang mempengaruhi kadar air briket, molekul pati pada perekat tersebut juga mempunyai gugus hidrofilik yang dapat menyerap air sesuai dengan kelembaban udara sekitarnya. Pane et al (2015), melaporkan bahwa konsentrasi perekat tapioka dan penambahan kapur memberi pengaruh nyata terhadap persentase kadar air briket pelepah aren.

Hasil analisis sidik ragam pengaruh perlakuan terhadap variabel respon briket dari biomassa Imbah penyulingan minyak kayu putih diperlihatkan pada Tabel 2.

Tabel 2. Rekapitulasi Analisis Sidik Ragam Pada Berbagai Variabel Respon Briket.

\begin{tabular}{lccccc}
\hline \multirow{2}{*}{ Sumber keragaman } & $\begin{array}{c}\text { Derajat } \\
\text { bebas }\end{array}$ & $\begin{array}{c}\text { Kadar } \\
\text { air }\end{array}$ & Density & Kadar abu & $\begin{array}{c}\text { Bagian yang hilang } \\
\text { pada suhu 950 } \mathbf{C}\end{array}$ \\
\hline Persentase Perekat organik (A) & 5 & $430,95^{* *}$ & $324,07^{* *}$ & $73,58^{* *}$ & $184,76^{* *}$ \\
Jenis Perekat (B) & 1 & $5,97^{*}$ & $193,42^{* *}$ & $203,11^{* *}$ & $48,55^{* *}$ \\
Interaksi Faktor AB & 5 & $6,69^{* *}$ & $3,74^{*}$ & $1,35^{\text {tn }}$ & $2,18^{\text {tn }}$ \\
Galat & 36 & & & & \\
Total & 48 & & & \\
\hline Keterangan: & ${ }^{*}$ Nyata & ${ }^{* *}$ Sangat nyata & tn : Tidak nyata & &
\end{tabular}


Untuk mengetahui berapa besar kontribusi dari perlakuan penggunaan jumlah perekat sagu terhadap kadar air biobriket dihasilkan dan keeratan hubungan antara kedua variabel tersebut, dilakukan analisis regresi korelasi. Hasil analisis regresi (Tabel 3) yang sebelumnnya telah diuji distribusi data, keberartian regresi dan uji keberartian koefisien korelasi antara variabel prediktor dan variabel respon menunjukkan bahwa hubungan antara perlakuan penggunaan perekat sagu dengan variabel respon kadar air biobriket akan mengikuti persamaan garis $\hat{Y}=23,71-0,91 X$ dengan koefiesien korelasi, $R=-0,907$ dan koefiesien determinasi, $R^{2}=0,823$. Sedangkan pada penggunaan perekat tapioka, hubungan antara kedua variabel tersebut mengikuti persamaan garis $\hat{Y}=23,71-0,91 X$ dengan koefisien korelasi $R=-0,824$ dan koefiesien determinasi, $R^{2}=0,678$

Dari koefisien determinasi yang diperoleh menunjukkan bahwa $82,3 \%$ variasi yang terjadi pada kadar air biobriket yang dihasilkan dipengaruahi oleh perlakuan. Nilai kadar air biobriket yang dibuat belum memenuhi standar mutu dan karakteristik briket untuk rumah tangga kecuali briket yang dibuat dengan perlakuan $a_{6}$ $b_{1}$ dan $a_{6} b_{2}$, kadar airnya lebih kecil dari $7,5 \%$. Kadar air yang direkomendasikan untuk penyimpanan dan daya bakar yang baik sekitar $12-20 \%$, dimana bila kadar airnya melebihi $20 \%$ akan menghabiskan banyak energi selama pembakaran (Idah and Mopah 2013). Kadar air yang rendah menghasilkan nilai kalor yang tinggi dan memudahkan dalam penyalaan atau pembakaran awalnya. Sebaliknya, persentase kadar air yang tinggi akan menyebabkan nilai kalor briket yang dihasilkan tersebut menurun dan juga memungkinkan untuk tumbuhnya mikroba (Ismayana dan Afriyanto 2011).

Hubungan antara penggunaan perekat sagu dengan variabel respon biobriket diperlihatkan pada Tabel 2.

Tabel 3. Hubungan Antara Penggunaan Perekat Sagu Dan Variabel Respon Biobriket

\begin{tabular}{lccccc}
\hline Peubah respon & Persamaan regresi & $\begin{array}{c}\text { Koefisien } \\
\text { korelasi }\end{array}$ & $\begin{array}{c}\text { Koefisien } \\
\text { determinasi }\end{array}$ & $\begin{array}{c}\mathbf{F}- \\
\text { hitung }\end{array}$ & Sig \\
\hline Kadar air & $Y=23,71-0,907 X$ & $-0,907^{* *}$ & 0,823 & $18,62^{* *}$ & 0,013 \\
Density & $Y=0,53+0,004 X$ & $0,997^{* *}$ & 0,995 & $733,02^{* *}$ & 0,000 \\
Kadar abu & $Y=2,413+0,048 X$ & $0,989^{* *}$ & 0,974 & $185,14^{* *}$ & 0,000 \\
$\begin{array}{ll}\text { Bagian yang } \\
\text { hilang pada suhu }\end{array}$ & $Y=17,16+0,098 X$ & $0,923^{* *}$ & 0,852 & $22,94^{* *}$ & 0,009 \\
$950^{\circ} C$ & & & & \\
\hline Keterangan: ${ }^{*}$ Nyata ${ }^{* *}$ Sangat nyata & & & &
\end{tabular}

Dari Tabel 3 dapat dijelaskan bahwa pola hubungan antara vaiabel prediktor penggunaan jumlah perekat tapioka dengan variabel respon kadar air biobriket mengikuti persamaan $\hat{Y}=$ $23,71-0,907 X$ dengan koefisien korelasi, $-0,907$ dan koefisien determinasi, 0,823. Pola hubungan ini menunjukkan bahwa makin banyak penggunaan perekat sagu pada pembuatan biobriket akan meningkatkan kadar air. Pola hubungan seperti ini biasanya disebut hubungan linear positip.

Hubungan antara vaiabel prediktor penggunaan jumlah perekat tapioka dengan variabel respon kadar air mengikuti persamaan $\hat{Y}$ $=21,20-0,102 X$ dengan koefisien korelasi,0,824 dan koefisien determinasi, 0,678. Trend garis yang sama juga terjadi pada biobriket yang dibuat menggunakan perekat sagu dimana hubungan variabel prediktor dengan kadar air biobriket mengikuti persamaan $\hat{Y}=23,71-$ $0,907 X$ dengan koefisien korelasi $-0,907$ dan koefisien determinasi 0,823 . Pola hubungan tersebut menunjukkan bahwa makin banyak penggunaan perekat tapioka maupun sagu pada pembuatan biobriket akan menurunkan kadar air, pola hubungan seperti ini biasanya disebut hubungan linear positif.

Hasil analisis regresi menunjukkan bahwa ada kontribusi dari non variabel prediktor pada penggunaan perekat tapioka dan sagu masingmasing sebesar $32,2 \%$ dan $17,7 \%$ terhadap nilai kadar air artinya variasi yang terjadi pada nilai tersebut dipengaruhi/terjelaskan oleh penggunaan perekat tapioka $89,5 \%$ dan perekat sagu $85,2 \%$.

Dari hasil uji signifikansi koefisien korelasi peubah respoan dengan peubah prediktor perekat sagu dan tapiokan terlihat bahwa koefisien korelasinya sangat nyata, menunjukkan bahwa hipotesis $H_{0}$ $\rho=0$ (tidak ada korelasi antar varibel) ditolak dan

$H_{1}: \rho \neq 0$ (ada korelasi antar variabel) diterima pada tingkat kepercayaan 99\%. Ditolaknya hipotesis $H_{0}$ berarti ada korelasi antara variabel prediktor dan variabel respon yang sangat nyata. Dari nilai koefisien korelasi yang diperoleh menunjukkan bahwa hubungan antara kedua variabel tersebut sangat kuat. 
Kadar Abu.

Kadar abu biobriket pada berbagai perlakuan jumlah perekat sagu dan tapioka berkisar antara 5,20-8,56\%. Kadar abu tertinggi dan terendah masing-masing terdapat pada biobriket yang dibuat menggunakan perekat sagu $130 \%$ dan perekat tapioka $80 \%$. Makin tinggi penggunaan jumlah perekat sagu dan tapioka pada pembuatan biobriket, cenderung mengakibatkan terjadi kenaikan kadar abu biobriket. Sedangkan penggunaan perekat sagu, rata-rata kadar abu biobriket yang dihasilkan lebih rendah $1,13 \%$ bila dibandingkan penggunaan perekat tapioka (Tabel1). Kadar abu pada berbagai perlakuan yang dicobakan memenuhi SNI briket arang kecuali perlakuan $a_{5} b_{1}$ dan $a_{6} a_{1}$ sedangkan bila acuan ke standar Amerika, kadar abu pada berbagai perlakuan memenuhi standar, namun peubah tersebut belum memenuhi standar bila acuannya standar Jepang.

Hasil analisa varians menunjukkan bahwa ada pengaruh yang sangat signifikan dari perlakuan penggunaan jumlah dan jenis perekat terhadap kadar abu biobriket sedangkan interaksi keduanya menunjukkan pengaruh yang tidak signifikan terhadap kadar air (Tabel 2). Dari hasil analisis ini terbukti secara empiris bahwa hipotesis $H_{0}$ dalam penelitian ini yaitu jumlah dan jenis perekat berpengaruh terhadap kadar abu biobriket diterima pada tingkat kepercayaan $99 \%$.

Untuk mengetahui perbedaan setiap perlakuan terhadap variabel respon biobriket dilakukan uji beda Tukey dan terlihat dari uji tersebut bahwa ada perbedaan kadar abu biobriket yang sangat signifikan antar perlakuan penggunaan jumlah perekat $a_{1}$ dengan $a_{2}-a_{6}$, namun tidak semua perlakuan berbeda nyata. Sedangkan uji beda kadar abu antar jenis perekat tapioka dan sagu menunjukkan perbedaan yang sangat nyata. Hal ini disebabkan karena makin banyak jumlah perekat tapioka dan sagu yang digunakan, makin tinggi kadar abu biobriket. Hasil penelitian Purwanto (2015), bahwa makin tinggi kadar abu makin rendah nilai kalor yang dihasilkan. Komponen unsur kimia abu pada umumnya mengandung kalsium, magnesium, natrium, mangan, besi, alumanium, seng, silika, tembaga, kromium dan tergantung dari jenis biomassa (Alpian et al 2011). Hendra (2011) menyatakan unsur - unsur kimia yang terkandung dalam abu dapat menurunkan nilai kalor bakar. Salah satu unsur dalam abu adalah silikat yang pengaruhnya kurang baik terhadap nilai kalor briket, dimana semakin rendah kadar abu maka semakin baik kualitas briket (Ndraha 2009). Pane et al (2015) dalam penelitiannya menunjukkan bahwa kadar abu briket pelepah aren meningkat dengan bertambahnya konsentrasi perekat tapioka $0 \%, 10 \%, 20 \%$ dan $30 \%$ pada konsentrasi kapur yang konstan. Hasil penelitian kadar abu biobriket dari limbah penyulingan minyak kayu putih ini sejalan dengan hasil penelitian Pane et al (2015), bahwa ada korelasi positip antara jumlah penggunaan perekat tapioka dan sagu terhadap kadar abu biobriket. Onchieku et al (2012) dalam penelitiannya menunjukkan bahwa peningkatan jumlah komposisi bahan tambahan pada briket membuat persentase kadar abu semakin tinggi. Bila hasil penelitian ini dihubungkan dengan penelitian dari Onchieku et al (2012) terlihat ada kesesuaian bahwa peningkatan kadar abu biobriket limbah penyulingan minyak kayu putih akibat dari peningkatan penggunaan komposisi bahan tambahan perekat. Menurut Supatata et al (2013), kadar abu seharusnya lebih rendah dari $4 \%$ karena biomassa dengan kadar abu tinggi banyak terdiri atas logam - logam alkalin. Komponen tersebut ini membuat temperatur fusi rendah yang potensial membentuk kerak.

Hubungan antara penggunaan perekat tapioka dengan variabel respon biobriket diperlihatkan pada Tabel 4.

Tabel 4. Hubungan Antara Penggunaan Perekat Tapioka Dan Variabel Respon Biobriket

\begin{tabular}{lccccc}
\hline \multicolumn{1}{c}{ Peubah respon } & Persamaan regresi & $\begin{array}{c}\text { Koefisien } \\
\text { korelasi }\end{array}$ & $\begin{array}{c}\text { Koefisien } \\
\text { determinasi }\end{array}$ & F- hitung & Sig \\
\hline Kadar air & $\hat{Y}=21,20-0,102 X$ & $-0,824^{*}$ & 0,678 & $8,44^{*}$ & 0,044 \\
Density & $\hat{Y}=0,071+0,003 X$ & $0,986^{* *}$ & 0,973 & $143,18^{* *}$ & 0,000 \\
Kadar abu & $\hat{Y}=2,66+0,034 X$ & $0,964^{* *}$ & 0,928 & $51,88^{* *}$ & 0,002 \\
Bagaian yang hilang & $\hat{Y}=14,98+0,084 X$ & $0,946^{* *}$ & 0,895 & $34,20^{* *}$ & 0,004 \\
pada suhu 950 & ${ }^{* *}$ * & & & &
\end{tabular}

Dari Tabel 4 dapat dijelaskan bahwa pola hubungan antara vaiabel prediktor penggunaan jumlah perekat tapioka dengan variabel respon kadar abu biobriket mengikuti persamaan $\hat{Y}=$ $2,66+0,034 X$ dengan koefisien korelasi, 0,964 dan koefisien determinasi, 0,928 . Pola hubungan tersebut menunjukkan bahwa makin banyak penggunaan perekat tapioka pada pembuatan biobriket akan meningkatkan kadar abu biobriket yang dihasilkan, pola hubungan seperti ini biasanya disebut hubungan linear positip. 
Hasil analisis regresi menunjukkan bahwa ada kontribusi dari non variabel prediktor sebesar $7,2 \%$ terhadap nilai kadar abu biobriket artinya variasi yang terjadi pada nilai kadar abu biobriket dipengaruhi/terjelaskan $92,8 \%$ oleh variabel prediktor. Dari hasil uji signifikansi koefisien korelasi terlihat bahwa koefisien korelasi sangat nyata, menunjukkan bahwa hipotesis $H_{0}$

$\rho=0$ (tidak ada korelasi antar varibel) ditolak dan

hipotesis

$H_{1}: \rho \neq 0$ (ada korelasi antar variabel)

diterima pada tingkat kepercayaan 99\%. Ditolaknya hipotesis $H_{0}$ berarti ada korelasi antara variabel prediktor dan variabel respon yang sangat nyata. Nilai koefisien korelasi yang diperoleh menunjukkan bahwa hubungan antara kedua variabel tersebut sangat kuat.

\section{Kerapatan.}

Kerapatan biobriket limbah penyulingan minyak kayu putih yang dibuat dengan berbagai perlakuan jumlah perekat sagu dan tapioka berkisar antara $0,35-0,58 \mathrm{~g} / \mathrm{cm}^{3}$ kerapatan tertinggi dan terendah masing-masing terdapat pada biobriket yang dibuat menggunakan perekat sagu $130 \%$ dan perekat tapioka $80 \%$. Makin tinggi penggunaan jumlah perekat sagu dan tapioka pada pembuatan biobriket, cenderung mengakibatkan terjadi kenaikan kerapatan biobriket. Sedangkan penggunaan perekat sagu, rata-rata kerapatan biobriket yang dihasilkan lebih rendah 6,97\% bila dibandingkan penggunaan perekat tapioka (Tabel1). Hasil analisa varians menunjukkan bahwa ada pengaruh yang sangat signifikan dari perlakuan penggunaan jumlah dan jenis perekat terhadap kerapatan biobriket sedangkan interaksi keduanya menunjukkan pengaruh yang tidak signifikan terhadap kerapatan (Tabel 2). Dari hasil analisis ini terbukti secara empiris bahwa hipotesis $H_{0}$ yaitu jumlah dan jenis perekat berpengaruh terhadap kerapatan biobriket diterima pada tingkat kepercayaan 99\%. Selanjutnya uji beda Tukey menunjukkan bahwa terdapat perbedaan kerapatan biobriket dengan tingkat signifikan yang berbeda antar perlaknuan jumlah penggunaan perekat organik. Hal ini disebabkan karena perbedaan homogenitas campuran pada setiap perlakuan. Pada penggunaan perekat tapioka 130\% menunjukkan bahwa kondisi campuran antara perekat dengan serbuk limbah daun kayu putih sudah optimal. Ini terindikasi sudah tercapai ikatan maksimum antara kedua bahan tersebut. Semakin besar penambahan perekat sagu maupun tapioka, semakin besar pula kerapatan briket yang dihasilkan. Namun briket dengan kerapatan yang terlalu rendah dapat mengakibatkan briket cepat habis dalam pembakaran karena bobot briketnya lebih rendah ( Hendra dan Winarni 2003).

Dari hasil uji Tukey terhadap penggunaan jenis perekat, terlihat bahwa ada perbedaan kerapatan yang sangat signifikan pada briket yang dibuat menggunakan perekat sagu dan tapioka. Penggunaan perekat sagu, rata-rata kerapatan biobriket yang dihasilkan lebih rendah $6,97 \%$ bila dibandingkan penggunaan perekat tapioka (Tabel 1). Hal ini disebabkan karena perbedaan daya rekat dari kedua jenis perekat tersebut. Pada perekat yang daya rekatnya kecil mengakibatkan lebih banyak porisitas yang terbentuk pada biobriket dibandingkan perekat yang mempunyai daya rekat tinggi sehingga kerapatan biobriketpun akan berbeda. Daya rekat dari perekat organik dipengaruhi oleh kadar amilosa dan amilopektin yang merupakan komponen penyusun pati, amilosa berguna untuk memberikan efek keras sedangkan amilopektin untuk memberikan efek lengket. Tingginya kerapatan pada briket yang menggunakan perekat tapioka dari pada briket yang menggunakan perekat sagu disebabkan karena kandungan amilopektin pada perekat tapioka lebih tinggi (73\%) dari pada perekat sagu $(82,13 \%)$ (Ndraha 2009).

Pola hubungan antara vaiabel prediktor penggunaan jumlah perekat tapioka dengan variabel respon kerapatan biobriket mengikuti persamaan $\hat{Y}=0,07+0,003 X$ dengan koefisien korelasi, 0,986 dan koefisien determinasi, 0,973. Sedangkan hubungan penggunaan perekat sagu dengan kerapatan biobriket mengikuti persamaan $\hat{Y}=0,53+$ $0,004 X$, koefisien korelasi 0,997 dan koefisien determinasi 0,995 . Pola hubungan tersebut menunjukkan bahwa makin banyak penggunaan perekat tapioka maupun sagu pada pembuatan biobriket akan meningkatkan kerapatan biobriket tersebut, pola hubungan seperti ini disebut hubungan linear positip.

Hasil analisis regresi juga menunjukkan bahwa ada kontribusi dari variabel prediktor penggunaan perekat tapioka dan sagu masingmasing sebesar $97,3 \%$ dan $99,7 \%$ terhadap nilai kerapatan biobriket, artinya variasi yang terjadi pada nilai kerapatan biobriket dipengaruhi/terjelaskan $97,3 \%$ oleh penggunaan perekat tapioka dan $99,7 \%$ oleh penggunaan perekat sagu. Dari hasil uji signifikansi koefisien korelasi antara variabel prediktor dengan variabel respon terlihat bahwa koefisien korelasi sangat nyata, menunjukkan bahwa hipotesis $H_{0}$ : $\rho=0$ (tidak ada korelasi antar varibel) ditolak dan hipotesis

$H_{1}: \rho \neq 0$ (ada korelasi antar variabel)

diterima pada tingkat kepercayaan 99\%. Ditolaknya hipotesis $H_{0}$ berarti ada korelasi antara variabel prediktor dan variabel respon 
yang sangat nyata. Nilai koefisien korelasi yang diperoleh dari analisis ini menunjukkan bahwa hubungan antara kedua variabel tersebut sangat kuat.

\section{Zat Yang Hilang Pada Suhu $950^{\circ} \mathrm{C}$}

Kadar zat yang hilang pada suhu $950^{\circ} \mathrm{C}$ adalah zat yang dapat menguap sebagai hasil dekomposisi senyawa- senyawa yang masih terdapat di dalam briket arang selain air, karbon terikat dan abu. Kadar zat yang hilang pada suhu $950^{\circ} \mathrm{C}$ yang diperoleh pada penelitian ini berkisar antara 4,27 - 10,44\% hasil ini belum memenuhi standar SNI kecuali biobriket yang dibuat dengan perekat tapioka $130 \%$, dimana kadar zat yang hilang pada suhu $950^{\circ} \mathrm{C}$ menurut SNI yaitu maksimal 5\% tetapi belum memenuhi standar briket buatan Jepang, Inggris dan Amerika. Makin tinggi penggunaan jumlah perekat sagu maupun tapioka pada pembuatan biobriket, cenderung mengakibatkan terjadi kenaikaan zat yang hilang pada biobriket bila dipanaskan pada suhu $950^{\circ} \mathrm{C}$. Sedangkan penggunaan perekat sagu, rata-rata zat biobriket yang hilang lebih tinggi $8,01 \%$ bila dibandingkan penggunaan perekat tapioka (Tabel 1).

Hasil analisa varians menunjukkan bahwa ada pengaruh yang sangat signifikan dari perlakuan penggunaan jumlah dan jenis perekat terhadap zat biobriket yang hilang sedangkan interaksi keduanya menunjukkan pengaruh yang tidak signifikan terhadap variabel respon tersebut (Tabel 2). Dari hasil analisis tersebut terbukti secara empiris bahwa hipotesis $H_{0}$ dalam penelitian ini diterima pada tingkat kepercayaan $99 \%$.

Untuk mengetahui perbedaan setiap perlakuan terhadap zat biobriket yang hilang pada pemanasan $950^{\circ} \mathrm{C}$, dilakukan uji Tukey dan terlihat dari uji tersebut bahwa ada perbedaan respon biobriket yang sangat signifikan antar perlakuan penggunaan jumlah perekat terhadap zat biobriket yang hilang kecuali perlakua $\mathrm{n} a_{3}$ $a_{4}$ dan $a_{4}-a_{5}$. Sedangkan uji beda zat biobriket yang hilang pada penggunaan jenis perekat tapioka dan sagu menunjukkan perbedaan yang sangat nyata. Hal ini disebabkan karena adanya perbedaan jumlah kandungan zat-zat mudah menguap yang terdapat pada perekat tapioka dan perekat sagu. Saputro et al (2012), mengemukakan kandungan zat terbang tinggi mempunyai beberapa keuntungan diantaranya penyalaan dan pembakaran lebih mudah, tetapi mempunyai kelemahan yaitu kadar karbon terikat yang rendah. Komponen utama zat mudah menguap tersusun atas $\mathrm{CO}, \mathrm{H}_{2}, \mathrm{CO}_{2}, \mathrm{CH}_{4}$ dan $\mathrm{H}_{2} \mathrm{O}$ dimana zat yang teruapkan masih mengandung zat-zat yang mudah terbakar. Sedangkan menurut Hendra (2011), kandungan kadar zat terbang tinggi akan menimbulkan asap lebih banyak pada saat briket dinyalakan, hal ini disebabkan oleh adanya reaksi antara karbon monoksida (CO) dengan turunan alkohol yang ada pada briket.

Hubungan antara vaiabel prediktor penggunaan jumlah perekat tapioka dengan variabel respon zat biobriket yang hilang pada pemanasan $950^{\circ} \mathrm{C}$ mengikuti persamaan $\hat{Y}=$ $14,98+0,084 X$ dengan koefisien korelasi, 0,946 dan koefisien determinasi, 0,895. Trend garis yang sama juga terjadi pada biobriket yang dibuat menggunakan perekat sagu dimana hubungan variabel prediktor dengan zat yang hilang pada biobriket mengikuti persamaan $\hat{Y}=17,16+0,098 X$ dengan koefisien korelasi 0,923 dan koefisien determinasi 0,852. Pola hubungan tersebut menunjukkan bahwa makin banyak penggunaan perekat tapioka maupun sagu pada pembuatan biobriket akan meningkatkan zat biobriket yang hilang pada pemanasan $950^{\circ} \mathrm{C}$, pola hubungan seperti ini biasanya disebut hubungan linear positif.

Hasil analisis regresi menunjukkan bahwa ada kontribusi dari non variabel prediktor pada penggunaan perekat tapioka dan sagu masingmasing sebesar $10,5 \%$ dan $14,8 \%$ terhadap nilai zat biobriket yang hilang artinya variasi yang terjadi pada nilai tersebut dipengaruhi/terjelaskan oleh penggunaan perekat tapioka $89,5 \%$ dan perekat sagu $85,2 \%$.

Dari hasil uji signifikansi koefisien korelasi terlihat bahwa koefisien korelasi sangat nyata, menunjukkan bahwa hipotesis $H_{0}$ : $\rho=$ 0 (tidak ada korelasi antar varibel) ditolak dan hipotesis

$H_{1}: \rho \neq 0$ (ada korelasi antar variabel) diterima pada tingkat kepercayaan $99 \%$. Ditolaknya hipotesis $H_{0}$ berarti ada korelasi antara variabel prediktor dan variabel respon yang sangat nyata. Dari nilai koefisien korelasi yang diperoleh menunjukkan bahwa hubungan antara kedua variabel tersebut sangat kuat.

\section{Nilai Kalor}

Nilai bakar atau nilai kalor merupakan nilai yang menunjukkan kandungan energi dalam bahan bakar (Aina et al 2009). Berbeda dengan bahan bakar kayu dimana terdapat keragaman dalam jenis dan sifat dari masingmasing jenis sedangkan karakteristik limbah daun kayu putih memiliki keragaman kadar air sedangkan komponen kimia dan jenis senyawa pada daun kayu putih relatif sama.

Hasil penelitian menunjukkan bahwa ratarata nilai kalor limbah daun kayu putih sebesar $4567,19 \mathrm{kal} / \mathrm{g}$. Nilai kalor ini memenuhi standar mutu dan karakteristik briket untuk rumah tangga karena kalornya lebih besar dari 4000 $\mathrm{kal} / \mathrm{g}$. Namun nilai ini lebih rendah dibandingkan dengan kalor arang tempurung kelapa tetapi 
lebih tinggi dari briket sekam padi 3.072,76 kal/g (Jamilatun 2008). Semakin tinggi nilai kalor briket, semakin baik kualitasnya. Menurut Ismayana dan Afriyanto (2011), kualitas nilai kalor briket akan meningkat seiring dengan bertambahnya bahan perekat dalam briket tersebut. Bahan perekat memiliki sifat dapat meningkatkan nilai kalor karena mengandung unsur C (Manik 2010). Kecepatan nyala briket dipengaruhi oleh kadar carbon dalam briket, kadar carbon yang rendah membuat briket lebih lama menyala. Semakin tinggi kadar carbon terikat menyebabkan nilai kalor juga semakin tinggi (Onchieku et al 2012). Selain kadar carbon yang mempengaruhi kalor briket, kadar abu juga berkontribusi terhadap variabel respon tersebut. Abu merupakan materi anorganik yang tersisa setelah pembakaran biomassa yang terdiri atas kalsium, magnesium, fosfor dan lainnya (Librenti et al 2010). Silikat merupakan salah satu unsur dalam abu yang pengaruhnya kurang baik terhadap nilai kalor briket. Penelitian tentang penggunaan perekat kanji dan tapioka pada pembuatan briket yang dilakukan oleh Lestari et al (2010), menunjukkan bahwa penambahan jumlah perekat berpengaruh pada kalori pembakaran briket dari tongkol jagung. Semakin tinggi jumlah perekat yang digunakan, nilai kalor memperlihatkan trend yang semakin menurun. Briket yang menggunakan perekat kanji nilai kalornya lebih tinggi dibandingkan menggunakan perekat sagu.

\section{KESIMPULAN}

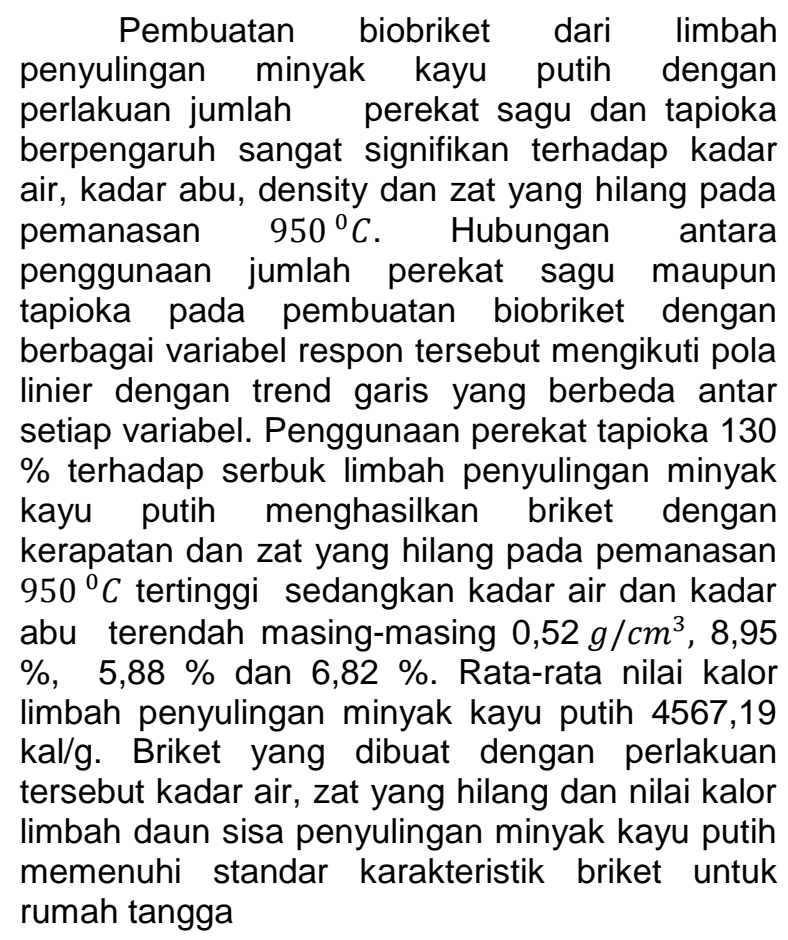

\section{DAFTAR PUSTAKA}

Abdullah, K. 2002. Biomass energy potential and utilization in Indonesia. IPB Bogor.

Aina, O.M., Adetogun, A.C., Iyiola, K.A. 2009. heat energy from value-added sawdust briquettes of Albizia Zygia, Ethiopian. Journal of Environmental Studies and Managemen 2(1) : 42-49.

Anshori, A.M., dan Sumertajaya, I M. 2000. Perancangan percobaan dengan aplikasi SAS dan minitab. Edisi kesatu IPB PRESS : Bogor.

Alpian, Prayitno, T.A., Sutapa, G.J.P., \& Budiadi. 2011. Kualitas arang kayu gelam (Melaleuca cajuputi). Jurnal Ilmu dan Teknologi Kayu Tropis 2 (1) :141 - 152.

Bahri, S. (2008). Pemanfaatan limbah industri kayu untuk pembuatan briket arang dalam mengurangi pencemaran lingkungan di Nangroe Aceh Darussalam. Thesis. Program Pendidikan Pasca Sarjana, USU, Medan.

BPS, 2014. Maluku Dalam Angka. Katalog BPS 1102001.81.

BPS, 2015. Maluku Dalam Angka. Katalog BPS 1102001.81.

Gomez, R., Gallego, E., Fuentesa, J.M., Montellano, G.C., dan Ayuga, F., 2014. Values for particle-scale properties of biomass briquettes made from agroforestry residues. Particuology $12: 100-106$.

Hambali, E., Mujalipah, dan Haloman, A. 2008. Teknologi Bioenergi. Agro Media : Jakarta.

Hendra, D. 2011. Pemanfaatan eceng gondok (Eichornia crassipes) untuk bahan baku briket sebagai bahan bakar alternatif. Jurnal Penelitian Hasil Hutan 29 (2) : 189 $-210$.

Hendra, D., dan Winarni, I. 2003. Sifat Fisis dan kimia briket arang campuran limbah kayu gergajian dan sabetan kayu. Buletin Hasil Penelitian Hutan 21 (3) : 211-226.

Ismayana A., dan Afriyanto, M.R. 2011. Pengaruh jenis dan kadar bahan perekat pada pembuatan briket blotong sebagai bahan bakar alternative. Jurnal Teknologi Industri Pertanian 21 (3) : 186193. 
Idah, P.A., and Mopah, E.J. 2013. Comparative assess ment of energy values of briquettes from some agricultural byproducts with different binders. IOSR Journal of Engineering. 3 (1) : 36-42.

Jamilatun, S. 2008. Sifat-sifat penyalaan dan pembakaran briket biomassa, briket batubara dan arang kayu. Jurnal Rekayasa Proses. 2 (2) : 65-72.

Jianfeng, S., Shuguang, Z., Xinzhi, L., Houlei, Z., and Junjie, T. 2010. The prediction of elemental composition of biomass based on proximate analysis. Energy Conversion and Management. 51 : 983987

Kong, G.T. 2010. Peran biomassa bagi energi terbarukan. PT Elex Media Kompurindo : Jakarta.

Longjian, C., Xing, L., and Lujia, H. 2009. Renewable energy from agro-residues in china: solid biofuels and biomass briquetting technology renewable and sustainable energy reviews. Renewable and Sustainable Energy 13 : 2689-2695

Librenti L, Ceotto E., Di Candilo M. 2010. Biomass characteristics and energy contents of dedicated lignocellulosic crops, Third International Symposium of Energy from Biomass and Waste.

Lestari, L., Aripin, Yanti, Zainudin, Sukmawati, dan Marliani. 2010. Analisis kualitas briket arang tongkol jagung yang menggunakan bahan perekat sagu dan kanji. Jurnal Aplikasi Fisika 6 (2) : 93-96.

Manik, F.S. 2010. Pemanfaatan spent bleaching earth dari proses pemucatan cpo sebagai bahan baku briket. Perpustakaan Institut Pertanian Bogor : Bogor.

Maryono, Sudding dan Rahmawati. 2013. Pembuatan dan analisis mutu briket arang tempurung kelapa ditinjau dari kadar kanji. Jurnal Chemical 14 (1) : 74-83.

Ndraha, N. 2009. Uji komposisi bahan pembuat briket bioarang tempurung kelapa dan serbuk kayu terhadap mutu yang dihasilkan. Universitas Sumatera Utara : Medan.

Onchieku, J.M, B.N. Chikamai, M.S. Rao. 2012. Optimum parameters for the formulation of charcoal briquettes using bagasse and clay as binder. European Journal of Sustainable Development, 1 (3) : 477 492.

Pane, J.P., Junary, E., dan Herlina, N. 2015. Pengaruh konsentrasi perekat tepung tapioka dan penambahan kapur dalam pembuatan briket arang berbahan baku pelepah aren (Arenga pinnata). Jurnal Teknik Kimia USU 4 (2) : 32-38.

Permatasari, I.Y., Utami, B. 2015. Pembuatan dan karakteristik briket arang dari limbah tempurung kemiri (aleurites moluccana) dengan menggunakan varisasi jenis bahan perekat dan jumlah bahan perekat. prosiding seminar nasional kimia. Jurdik FMIPA Kimia UNY : 59-69.

Purwanto, D. 2015. Pengaruh ukuran partikel tempurung sawit dan tekanan kempa terhadap kualitas biobriket. Jurnal Penelitian Hasil Hutan. 33 (4) : 303-313.

Putro, S., Musabbikhah, dan Hartati, S. 2013. Variasi parameter biomassa untuk meminimasi kadar air biobriket guna menciptakan energi alternatif yang murah dan ramah lingkungan. Dalam : Prosiding Simposium Nasional RAPI ke XII Universitas Muhammadiyah Surakarta, Surakarta, hal : 79-86

Sutiyono. 2002. Pembuatan briket arang dari tempurung kelapa dengan bahan pengikat tetes tebu dan tapioka. Jurnal Kimia dan Teknologi.10 : 217-222.

Saptoadi, Untoro, B., Surono, Nugroho, A.,Pambudi, dan Sudarwanto. 2009. Utilization of indigenous biomass wastes as low cost alternative fuels. International Conference on Alternative Energy Applications.

Saputro, D. D., Widayat, W., Rusiyanto, Saptoadi, H., Fauzun. 2012. Karakterisasi briket dari limbah pengolahan kayu sengon dengan metode cetak panas. Seminar Nasional Aplikasi Sains dan Teknologi, Periode III. Yogyakarta: IST AKPRIND.

Simone, P.P., Francesco, V., Adriano, M.L., dan Mentore, V. 2014. Design and performance assessment of a rice husk fueled stove for household cooking in a typical sub-saharan setting. Energy for Sustainable Development 23 : 15-24. 
Stolarski, M. J., Szczukowski, S., Tworkowski, J., Krzyžaniak, M., Gulczyňski, P. and Mleczek, M. 2013. Comparison of quality and production cost of briquettes made from agricultural and forest origin biomass. Renewable energy 57 (1) : 20-26.

Supatata, N., Buates ,J., Hariyanont, P. (2013) Characterization of Fuel Briquettes Made from Sewage Sludge Mixed with Water Hyacinth and Sewage Sludge Mixed with Sedge. International Journal of Environmental Science and Development. 4(2). 179-181.

Tim Pengembangan Biomassa Departemen Kehutanan. 2007. Pola pengembangan biomassa sebagai sumber energi. Bogor.

Tampubolon, A.P. 2008. Kajian kebijakan energi biomassa kayu bakar. Jurnal Analisis Kebijkan Kehutanan 5 (1) : 29-37.

Zhang, J., dan Guo, Y. 2014. Physical properties of solid fuel briquettes made from caragana korshinskii kom. Powder Technology 256 : 293-299.

Zulfian, Farah D., Setyawati D., Nurhaida, Roslinda E. 2015. Kualitas biopelet dari limbah batang kelapa sawit pada berbagai ukuran serbuk dan jenis perekat. Jurnal Hutan Lestari 3 (2) : 208-216. 